\title{
Research Regarding the Romanian Consumer Behavior for Alcoholic and Non-alcoholic Beverages
}

\author{
Corina Pelau \\ Academy of Economic Studies, Bucharest, Romania
}

\begin{abstract}
In this article there are analyzed the results of a research about the cognitive and emotional reactions of the Romanian consumer in the buying decision process for alcoholic and non-alcoholic beverages. The research focuses on a range of buying behavior types, trying to determine if the consumers have a rather cognitive or a rather emotional behavior in the case of beverages. Besides the differences observed for different target groups, there are also analyzed the impact which this type of behavior on the success of the strategies of beverage producers and retailers. The results of the research show a mixed behavior in the case of beverages and no major differences between alcoholic and non-alcoholic beverages. Consequently companies should combine emotional communication instruments with information based ones.
\end{abstract}

Keywords: consumer behavior, emotional and cognitive decisions, buying decision, beverages.

\section{Introduction}

Researchers have tried to understand and describe the behavior of humans for many years. Especially in the field of consumer research, the knowledge and understanding of human behavior can influence the communication campaigns of companies. The better we understand the behavior of a consumer the easier is it to influence his buying decision. This article describes several models, which try do describe the consumer behavior and the motives which lead to it. Besides this, based on the analyzed models, there are presented the results of a research about the motives of Romanian consumer to buy alcoholic and non-alcoholic beverages. Different studies have shown that consumer behavior differs on one hand depending on the characteristics of the consumer and on the other hand depending on the type of products. As Pelau (2011) mentions, there are products, where the decision is taken in a more rational way and products, where the decision is taken in a rather emotional way. In this article, there are presented the results of a research regarding the cognitive and emotional elements, which influence the buying decision of men and women towards alcoholic and non-alcoholic beverages and the impact this behavior has on the marketing strategy of producers and retailers.

Buying Behavior and its Influence on the Marketing Strategy

The analysis of consumer behavior has a great importance for research as it is not only a key factor for the success of companies, but it also gives a good insight in the society in

Copyright (C) 2012 Corina Pelau. This is an open access article distributed under the Creative Commons Attribution License unported 3.0, which permits unrestricted use, distribution, and reproduction in any medium, provided that original work is properly cited. Contact author: Corina Pelau E-mail: corinapelau@yahoo.com 
which the consumers live, its orientation an its values. Solomon et. al. (2010) mentions that the way in which the consumer feel and think is an important aspect for the company's strategies, because it is almost impossible to offer the customers the products they want and in the way they want. This fact is amplified in the recent years by the fact that the bought products don't represent anymore just some things which cover their basic needs, but they describe more and more the way he is, by the associated brand image of the products. Consequently the consumer buys the products not only to have them, but also to define their image, express their personality and consolidate their image in the society. Knowing the behavior and the complex motives, which drives the consumers to buy products, helps not only the producers, but also the retailers to develop their strategies. Moreover, Pop and Vladoi (2009) mention within the orientation of the marketing towards creating a relationship to the customer, these strategies have an increased influence on the vision and the mission of the companies, helping them to find new orientations.

Researchers have tried for many years to describe and determine the behavior of consumers, but because of the complexity of the decision it was quiet impossible to determine completely the behavior of the consumer. Several models have been developed to describe and determine some of the factors and processes that identify consumer's behavior and also their reaction. In the book of Catoiu and Teodorescu (2003) there are presented several theories of consumer behavior, which determine the processes of the consumer decision. For instance the consumer behavior theory of Marshal is based on Adam Smith's theory and states that the most important influencing factor is the price. The main contribution of this theory is that it includes the price as an economic cognitive element in the buying decision. The Pavlovian consumer behavior model states that the buying process contains four important phases: the impuls, the suggestion, the reaction and the next buying behavior. So the consumer behavior is determined by impuls and suggestion, from which results and immediate reaction and a future behavior. The consumer behavior model of Freud states that the buying decision is based on the motives a consumer has, but it is more complex than an impuls. The consumer behavior model of Veblenian is based on the ostentative consume, by which the consumer try to achieve a position in the society. Consequently the buying decision is influenced by several factors such as the culture, the subculture the social classes and reference groups. A research done by Pop and Pelau (2007) about the Romanian consumer has revealed several factors which determine the consumer to go shopping such as utility, socialization (or even as a spare time activity), special offers, preferences for trademarks and so on.

One of the most important theories in the field of consumer research, described in the book of Kroeber-Riel and Weinberg (2003) is the behaviorist SOR Model (stimuliorganismus-response). This model is complex and it includes more or less all the above mentioned models. It relies on the fact that there are three phases in the buying process. The first element is the stimuli from the environment which determines the buying decision. These stimuli can appear unconditioned in the environment (ex. a friend has a certain product and I want it too) or they can be transmitted by companies through different communication channels. The organismus represents the mind of the consumer in which the decision is formed, based on different elements such as cultural or educational background, social status, personality lifestyle. Because it is impossible to determine completely what happens in the mind of the consumers the researchers call it also the black-box of the consumer. Although not all processes in the mind of the consumer can be determined, researchers have identified two types of processes: cognitive processes and emotional processes. Foscht and Swoboda (2004) describe emotional processes as the ones which rely on the 
activation of internal emotions of a consumer, which lead to a certain behavior. Cognitive processes, as described by Foscht and Swoboda (2004), refer to some thinking procedures which take place together with the emotional processes in the mind of the consumer and include perception, learning, evaluation, memory and decision-making. The last element of the behaviorist model is the reaction. Based on the cognitive and emotional processes in the mind of the consumers, the reaction is reflected in the buying decision. This refers to the fact that a consumer buys or not a certain product and the type of product he buys.

\section{Buying Behavior for Alcoholic and Non- Alcoholic Beverages}

This article presents the results of a research about the consumer behavior and their buying motives. The research had as objective the analysis and exploration of the cognitive and emotional reactions in the buying behavior and the determination of the rationality from the point of view of the consumers. It consists of three parts. The initial part questioned the respondents on their initial purpose and desires of the buying process such as the products the consumer wanted to buy, the amount of money, the consumer wanted to spend and so on. The second part consists of an observation regarding the buying behavior. There were analyzed the reactions in the buying process for several product groups. The third part included a survey, which should explain the aspects observed in the previous part, regarding the motives of buying the products. The marketingexperiment was conducted in the period December 2010 - February 2011 in different retail formats in the main cities of Romania. There were observed 146 persons, which were chosen randomly by the interviewer. The only aspect which was considered in the marketing-experiment was that the number of female respondents should be equal to the number of male respondents. In this article, there are presented the questioned motives of the consumer regarding alcoholic and nonalcoholic beverages.

Beverages are products which are bought constantly by the consumers in different situations. For producers of alcoholic and non-alcoholic beverages it is interesting to analyze and to know the motives and the processes which take place in the mind of the consumers, while taking the decision what type of drink to buy. As the research shows, most of the consumers buy the same drinks all the time, because they know they are good. Other two frequent behaviors in the case of drinks is analyzing the best option and an emotional decision by which the consumers watches on the shelf and he buys the product he likes best. Despite this, the behavior of men and women differ, when choosing a certain type of drink. Depending on how the decision is taken, a company can influence the behavior by different means of communication.

As it can be observed in figure 1, the experience based behavior is more frequent for non-alcoholic beverages for women than men. $42,1 \%$ of the women buy the same beverages because they like it and only $37,1 \%$ of the men do so. This makes it very difficult for producers of beverages to convince consumer to change the bought product. The decision is usually taken, before the consumer gets into the store and for this reason in the case of these consumers, promotions in the store wouldn't influence much its decision. A frequent behavior for men is analyzing every time they go to a store, what the best option is. $15,7 \%$ of the men have this type of behavior while only $6.6 \%$ of the women do so. By this, the analytic behavior is the second most frequent behavior for men. According to the research in the case of non-alcoholic beverages only men base their decision on the price, while women don't do this. Anyway, there is a small importance of the price at buying nonalcoholic beverages. In comparison to this, women are more influenced by special offers, then men are. So $11,8 \%$ of the women buy 
non-alcoholic beverages because there is a special offer, while only $4.3 \%$ of the men do so. So, depending of the target group of a certain beverage, women can be easily attracted by special offers, while men are rather attracted by low prices.

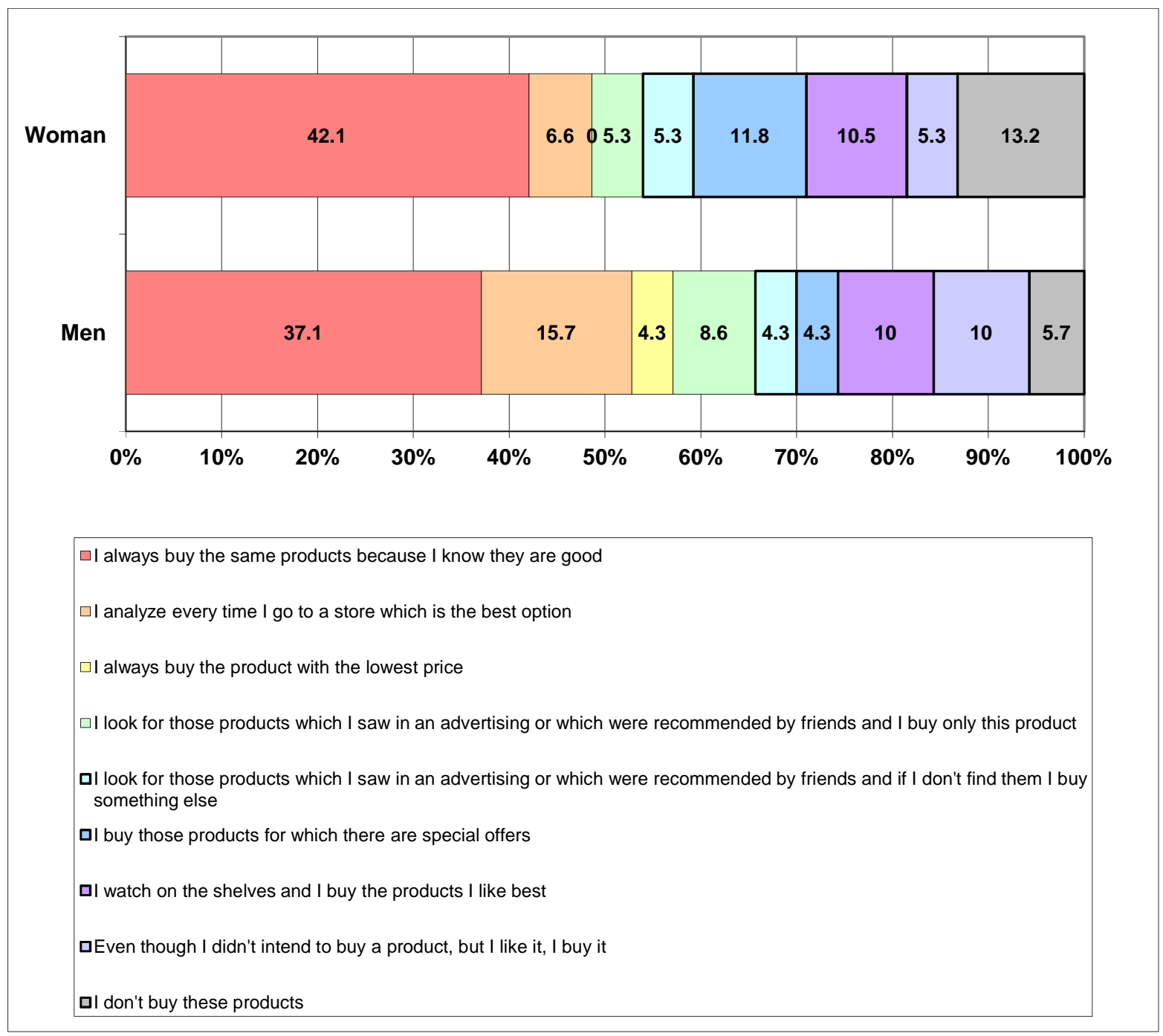

Fig 1. Buying Motives for Non-Alcoholic Beverages Depending on Gender

The influence of friends and advertising is higher in the case of men in comparison to women. So $12,9 \%$ of the men are influenced by friends and advertising, while only $8,6 \%$ of the women are. Besides this, women are more flexible, for only half of them would buy only the recommended products. In opposition to that, $8.6 \%$ of the men would buy only the recommended products, while $4.3 \%$ watch also other products, if they couldn't find the recommended one. Another frequent behavior both for women and for men is an emotional one, by which the consumers watch the products on the shelves and buy the one they like most. $10,5 \%$ of the women and $10 \%$ of the men have this type of behavior. The impulsive behavior by which a consumer buys a certain product, even if he didn't intended to do this, is in the case of non-alcoholic beverages more frequent at 
men then at women. So $10 \%$ of the men and only $5,3 \%$ of the women have this type of behavior. More women $(13,2 \%)$ then men $(5,7 \%)$ don't buy these products. An explanation for this could be either the fact that women were on diet or traditionally the men are the ones responsible for the drinks in a household.

In the case of alcoholic beverages the preponderant behavior is the experience based one, by which the consumers buy the same product because they like it, but the situation is different on gender. More women $(44.7 \%)$ have this type of behavior. This means that more women than men have this type of behavior and also that this type of behavior is more frequent at the women in the case of alcoholic beverages than in the case of non-alcoholic beverages (42.1\%). The experience based behavior for men is not the frequent $(32.9 \%)$ than in the case of nonalcoholic beverages. The explanation for this can be the fact that men are traditionally the ones who are in charge with the alcoholic beverages and they like to diversify the products. Another important behavior type is the analytical one, where $14.3 \%$ of the men and $9.2 \%$ of the women have this type of behavior. There is a similar value for men as in the case of non-alcoholic beverages, but the value is higher for women. In comparison to the price based behavior, which is not that frequent for non-alcoholic beverages, $2,6 \%$ of the women and $7.1 \%$ of the men buy the nonalcoholic beverages with the lowest price. These values change for special offers than in the case of alcoholic beverages. So, only 5.3\% of the women buy alcoholic beverages at special offers in comparison to $11.8 \%$ at nonalcoholic beverages and $7.1 \%$ of the men do so in comparison to $4.3 \%$ at non-alcoholic beverages. This happens probably because the men are the traditional alcoholic products buyer and they react more sensitive both at special offers and price reductions. 


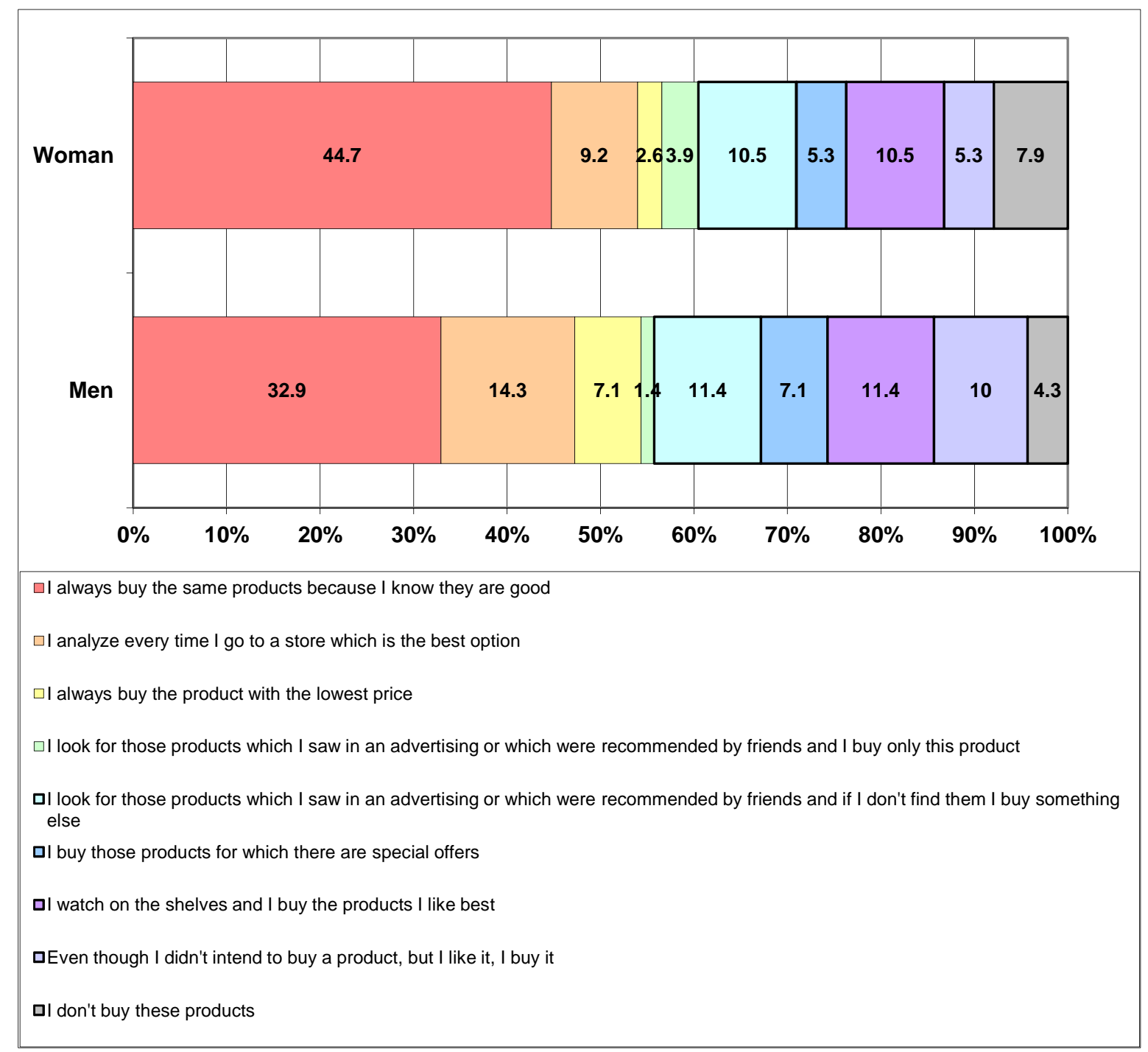

Fig 2. Buying Motives for Alcoholic Beverages Depending on Gender

The influence of advertising and friends is approximately the same in the case of men and it is higher in the case of women. Despite this, the flexibility is higher both for women and men in the case of non alcoholic products. So $12.8 \%$ of the men are influenced by friends and advertising and $14.4 \%$ of the women do so, but $10,5 \%$ of the women and $11,4 \%$ of the men would buy something else in the case that they don't buy the needed products. In the case of alcoholic products, the emotional behavior is more frequent at women than at men. $10.5 \%$ of the women and $11.4 \%$ of the men watch on the shelves and they buy the product they like best. 5.3\% of the women and $10 \%$ of the men buy products if they like them, although they didn't have this intention initially. This shows that the way, how a product looks and the way the products are arranged on the shelves can influence the decision of the consumer. For this reason companies should analyze the aspects which attract more at a product. $7.9 \%$ of the women and $4.3 \%$ of the men don't buy this type of products. Both percentages are lower than in the case of 
non-alcoholic beverages, which show that alcoholic products are bought more often than non-alcoholic ones.

\section{Conclusion}

The analysis of the consumer behavior gives companies precious information about the way they should design their marketing strategy. In the case of alcoholic and nonalcoholic beverages there is a mixed consumer behavior, which indicates a mixture of the marketing instruments. As observed in the article, the experienced based behavior is preponderant in both cases and both for women and for men. This shows the fact that the buying decision is often taken before the buying process and relies very often on the previous experiences. This fact makes it very difficult for new companies to convince the consumer to buy something else, because most of the consumers usually buy the same products, because they like them and because they know it. This type of behavior represents an advantage for the existent companies, but as mentioned, makes it difficult for new comers. Despite this, there is also a big amount of consumers, who are influenced by the advertising or by emotional components in the store. For this reason existent companies should advertise their products in order to keep the interests of the customers, while new comers should try to use these instruments in order to convince the customers to buy the products.

\section{Acknowledgment}

This work was supported from the European Social Fund through Sectoral Operational Programme Human Resources Development 2007-2013, project number POSDRU/ 89/ 1.5/ S/ 59184 "Performance and excellence in postdoctoral research in Romanian economics science domain".

\section{References}

Backhaus, K., Erichson, B., Plinke, W. \& Weiber, R. (2000). Multivariate Analysemethoden - _ Eine anwendungsorientierte Einfuehrung,
Springer, Berlin.

Balan, C. (2010). 'Present Shifts in Consumer Complaint Management,' in: Brătianu C., Lixăndroiu D., Pop N.A., Business Excellence, Proceedings of the 5th International Conference on Business Excellence, Volume I, Informarket Publishing House, Braşov.

Blythe, J. (1998). 'Comportamentul Consumatorului,' Teora, Bucuresti.

Catoiu, I. \& Teodorescu, N. (1997). 'Comportamentul Consumatorului: Teorie si Practica,' Editura Economica.

Catoiu, I. \& Teodorescu, N. (2003). 'Comportamnetul Consumatorului,' Uranus, București.

Foscht, T. \& Swoboda, B. (2004). Käuferverhalten: Grundlagen - Perspektiven - Anwendungen, Gabler, Wiesbaden.

Istudor, N. \& Pelau, C. (2011). 'Consumer Behavior on the Fruits and Vegetables Market,' at the international confernec European Integration - New Challenges, Oradea, 27-28 mai 2011, pg. 1759-1764.

Jimenez-Martin, S. \& Ladrón-de-Guevara, A. (2007). "Modeling Consumption Patterns in the Attribute Space: Theory and Evidence of Hybrid Behavior," in: International Journal of Research in Marketing, nr. 24, pg. 242-253.

Kroeber-Riel, W. \& Weinberg P. (2003). 'Konsumentenverhalten,' Vahlen, Münchent

Pelau, C. (2011a). 'Cognitive and Emotional Buying Decision of the Romanian Consumer,' at the conference „Provocările crizei si răspunsul stiintei economice”, Bucuresti, 1-2 iulie 2011.

Pelau, C. (2011b). 'Analysis of Consumer Behavior for Different Product Groups,' in Management \& Marketing, vol. 6, special issue/ 2011, pg. 101-114. 
Pop, C. M. \& Scridon, A. M. (2009). 'A Multinominal Logit Based Evaluation of Client's Preferences in the Cluj Napoca Retail Market,' in: Brătianu C., Lixăndroiu D., Pop N.A., Business Excellence, Proceedings of the 4th International Conference on Business Excellence, Volume II, Informarket Publishing House, Braşov, Romania, pp.106109.

Pop, N. Al. \& Pelau, C. (2007). 'Knowing the Motivation of Buying,' in: Analele universităţii din Oradea, seria: Ştiinţe economice, editura Universităţii din Oradea, Tom XVI, 2007, ediţie specială pentru conferința internaţională „Integrarea Europeană - Noi provocări pentru economia României“, ediţia 3-a, Oradea, May 2007, pg. 1063-1066.

Pop, N. Al. \& Pelau, C. (2011). 'Cognitive and Emotional Reactions in the Buying Decision and their Impact on the Success of Tehnological Changes,' in: Rusu, C.: Proceedings of the 7th International Conference on Management of Technological Changes, Alexandroupolis, Greece, September 2011, pg. 193-196.

Pop, N. Al. \& Vladoi, A. (2009). 'Characteristics of the Implementation of a Marketing Approach in the Romanian Companies,' in: Brătianu C., Lixăndroiu D., Pop N.A., Business Excellence, Proceedings of the 4th International Conference on Business Excellence, Volume II, Informarket Publishing House, Braşov, Romania, pp. 110113.

Solomon, M., Bamossy, G., Askegaard, S. \& Hogg, M. K. (2010). 'Consumer Behavior - A European Perspective,' 4 th edition, Prentice Hall, Financial Times, Harlow.
Swoboda, B., Berg, B. \& Dabija, D.C. (2009). 'Perception of Retail Marketing - Empirical Study on Formats,' in Brătianu C., Lixăndroiu D., Pop N.A., Business Excellence, Proceedings of the 4th International Conference on Business Excellence, Volume II, Informarket Publishing House, Braşov, Romania, pp.220-225. 